\author{
В. В. КОРОЛЕНКО, Т. С. ГРУЗЄВА, Г. В. ІНШАКОВА
}

\title{
АНАЛІЗ ПЕРСПЕКТИВ РОЗВИТКУ ДЕРМАТОВЕНЕРОЛОГІЧНОЇ СЛУЖБИ З УРАХУВАННЯМ ДУМКИ ПАЦІЄНТІВ ТА МЕНЕДЖЕРІВ ОХОРОНИ ЗДОРОВ'Я
}

\author{
Національний медичний університет імені О. О. Богомольця, м. Київ, Україна
}

\begin{abstract}
Мета: оцінити сучасний стан та проблеми надання дерматовенерологічної допомоги з позиції пацієнтів та менеджерів охорони здоров'я.

Матеріали і методи. Застосовано бібліографрічний, медико-статистичний, соціологічний методи. Науковою базою стали дані наукової літератури, дані власних соціологічних досліджень з вивчення думки пацієнтів та менеджерів охорони здоров'я щодо якості та доступності дерматовенерологічної допомоги.

Результати. Соціологічним дослідженням встановлено проблеми доступності та якості дерматологічної допомоги. Понад третина пацієнтів оцінила якнедостатню територіальну $(34,6 \pm 2,1$ на 100 опитаних $)$ та фрінансову $(31,3 \pm 2,0)$

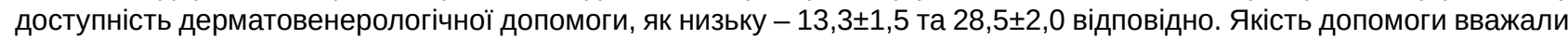
недостатньою 27,3 2,0 на 100 респондентів. Виявлено причини проблем і шляхи підвищення доступності та якості дерматологічної допомоги, у тому числі удосконалення організації обслуговування, запровадження електронної охорони здоров'я, поліпшення ресурсного забезпечення, комунікації. Менеджери охорони здоров'я вказали на причини недостатньої ефективності дерматовенерологічної допомоги, у тому числі недостатнє медичне оснащення $(71,9 \pm 3,9)$ та інформаційне забезпечення $(40,7 \pm 4,2)$, брак комп'ютерного обладнання $(57,8 \pm 4,3)$, незадовільну координацію діяльностіз колегами, допоміжними підрозділами, брак міжгалузевої взаємодії, відсутність мотиваційних важелів тощо. Виявлено потребу в запровадженні дистанційних технологій - телемедицини, мобільної медицини, а також в поширенні практики використання цифрової дерматоскопії, ультразвукової діагностики шкіри, патогістології шкіри, лазерних та радіохвильових апаратних технологій лікування. Підтверджено думку пацієнтів та менеджерів охорони здоров'я про негативний вплив пандемії COVID-19 на доступність і якість медичних послуг.

Висновки. Вивчення думки пацієнтів та менеджерів охорони здоров'я стосовно сучасного стану дерматовенерологічної служби, кадрового потенціалу, доступності та якості ії̈ послуг дозволило виявити низку організаційно-управлінських проблем та визначити пріоритети діяльності 3 подальшої розбудови системи дерматовенерологічної допомоги населенню за умов реформування охорони здоров'я, обґрунтувати концептуальні засади побудови її удосконаленої фрункціонально-організаційної моделі.
\end{abstract}

КЛЮчОВІ СЛОВА: організація медичної допомоги; дерматовенерологічна допомога; доступність; якість; пацієнти; менеджери; соціологічне дослідження; телемедичні технології; ресурсне забезпечення; COVID-19; реформування.

Система охорони здоров'я посідає надзвичайно важливе місце у житті суспільства. Здоров'я людини є складовою людського потенціалу і враховується при обчисленні індексу людського розвитку - інтегрального показника рівня соціальноекономічного розвитку кожної країни. Створення оптимальних умов для реалізації потенціалу кожної особи впродовж всього життя, досягнення європейських стандартів якості життя та благополуччя населення є також частиною зобов'язань у рамках «Угоди про асоціацію між Україною, 3 однієї сторони, та Європейським Союзом, Європейським співтовариством 3 атомної енергії і їхніми державами-членами, з іншої сторони», i, відповідно, рефрормування сфери охорони здоров'я нашої держави є однією з найважливіших цілей її розвитку в умовах сьогодення [2]. Важливе місце в контексті забезпечення умов для збереження і зміцнення здоров'я населення посідає профрі-

(c) В. В. Короленко, Т. С. Грузєва, Г. В. Іншакова, 2020 лактика та якісне лікування соціально значущих захворювань, а також розвиток медичних служб, однією з яких є дерматовенерологічна служба [1].

За умов трансорормації вітчизняної охорони здоров'я перед різними її компонентами постає безліч викликів організаційно-управлінського, економічного, правового характеру. Вони пов'язані з тенденціями в здоров'ї населення, змінами потреби в різних видах медичного обслуговування і, відповідно, їх координації та інтеграції, з імплементацією нових організаційних фрорм надання медичних послуг, їх фрінансування, управління ресурсами [4].

Досягнення цілей у сфері сталого розвитку, визначених Указом Президента України № 722/2019 «Про Цілі сталого розвитку України на період до 2030 року» [5], виданим 3 метою імплементації в Україні Цілей сталого розвитку ООН на 20162030 рр., передбачає забезпечення належного рівня здоров'я і благополуччя населення, що по- 
требує адаптації системи надання послуг охорони здоров'я відповідно до викликів та загроз XXI століття. 3 урахуванням процесів епідеміологічного переходу [10], які мають місце в Україні та інших країнах Європи, першочергові виклики здоров'ю включають проблеми соціально-небезпечних захворювань [3].

Прогрес у розвитку медичних технологій дозволяє істотно розширити обсяги наданих медичних послуг та охоплення ними населення 3 урахуванням збільшення кількості людей старших вікових груп, підвищити якість і доступність медичного обслуговування [13].

Актуальним $€$ забезпечення охоплення медичним обслуговуванням усіх вікових груп населення, поліпшення показників здоров'я і його детермінант протягом усього життєвого шляху, запровадження моделей надання медичної допомоги на основі оптимального набору популяційних втручань та орієнтовані на потреби людей індивідуальних послуг [7].

Новітній виклик для системи охорони здоров'я усіх країн світу - це координація надання послуг охорони здоров'я за умов поширення коронавірусної хвороби COVID-19. Система охорони здоров'я часто $є$ перевантаженою, знижується доступність необхідної медичної допомоги, зростає смертність через спалахи інших інфекційних хвороб та через неінфекційні захворювання, які потребують профрілактики і лікування [9].

Здатність будь-якої системи забезпечувати безперервне надання основних послуг охорони здоров'я залежить від базового тягаря захворювань і потенційних можливостей системи охорони здоров'я в міру розвитку пандемії. У цьому аспекті надзвичайно важливу роль відіграють інвестиції в первинну медичну допомогу та її координація зі спеціалізованими ланками [11].

Перед системою охорони здоров'я постали проблеми щодо збалансування потреб, пов'язаних із безпосереднім реагуванням на пандемію COVID-19, з необхідністю безперервного надання інших основних послуг охорони здоров'я. Насамперед це стосується забезпечення безпечного і ефективного потоку пацієнтів, удосконалення організації скринінгу на COVID-19, адресного направлення пацієнтів за відповідними маршрутами. Зменшенню ризику перевантаженості сприяють ефективні механізми управління і координації, а також протоколи для встановлення пріоритетності послуг та їх адаптації.

Серед пріоритетних питань медичного обслуговування населення потребують уваги проблеми кадрового забезпечення, підготовки та безперервного професійного розвитку кадрів, реалізації мультидисциплінарного підходу в процесі надання медичної допомоги, забезпечення доступності та якості [12].
Особливе місце займають проблеми розбудови спеціалізованих медичних служб, у тому числі дерматовенерологічної служби, робота якої спрямована на попередження та якісне лікування низки соціально небезпечних та соціально значущих захворювань.

Питання удосконалення надання дерматовенерологічної допомоги населенню є надзвичайно актуальними для України, де дерматози посідають 5 місце у структурі захворюваності хвороб [6]. В Україні щорічно реєструють близько 400 тис. нових випадків інфекцій, що передаються статевим шляхом. При цьому необхідно враховувати, що державна статистика через зміни епідеміологічних характеристик цих інфекцій та особливості їх статистичної звітності відображає не більше 40 \% реальної кількості випадків (за різними оцінками). Причиною цього є, поряд 3 іншим, те, що окремі групи населення (групи ризику) не мають безперешкодного доступу до належної дерматовенерологічної допомоги [3].

Дослідження особливостей та тенденцій дерматовенерологічного здоров'я засвідчили, що ця проблема залишається актуальною і вимагає пошуку нових підходів до її вирішення [8]. У даному контексті важливим $€$ аналіз думки споживачів медичних послуг, а також менеджерів - організаторів системи охорони здоров'я, що дозволить додатково осмислити міждисциплінарні та міжсекторальні підходи до організації надання дерматовенерологічної допомоги на всіх рівнях, врахування можливостей дистанційного скринінгу та моніторингу на засадах телемедицини та мобільної медицини.

Відсутність в Україні наукових робіт з комплексного вирішення проблем організації дерматовенерологічної допомоги за умов реформування охорони здоров'я 3 урахуванням міжнародних стандартів і підходів зумовили потребу в даному науковому дослідженні, визначили напрям наукового пошуку.

Мета дослідження: оцінити сучасний стан та проблеми надання дерматовенерологічної допомоги 3 позиції пацієнтів та менеджерів охорони здоров'я.

Матеріали і методи. Методологічна основа науково-дослідної роботи ґрунтується на системному підході. У роботі застосовано бібліографічний, медико-статистичний, соціологічний методи.

Дослідження виконано в рамках науководослідної роботи Національного медичного університету імені О. О. Богомольця на тему «Медико-соціальне обґрунтування оптимізації організації медичної допомоги в умовах розвитку системи громадського здоров'я» (№ держреєстрації 0120U100807).

Науковою базою стали джерела вітчизняної та зарубіжної літератури за темою дослідження, 
дані власних соціологічних досліджень з вивчення думки пацієнтів щодо доступності та якості медичної допомоги дерматовенерологічного профрілю, а також думки менеджерів охорони здоров'я щодо ризиків трансорормації дерматовенерологічної служби за умов реформування охорони здоров'я. Інструментарієм соціологічного дослідження слугувала спеціальна анкета, за допомогою якої проводили анонімне вивчення думок респондентів. До соціологічного дослідження пацієнтів долучилися 512 осіб, з яких 46,9 \% становили чоловіки і 53,1 \% - жінки. За віком респондентів поділили таким чином: 18-25 років - 19,3\% опитаних, 26-35 років - 24,8\%, 36-45 років 25,8 \%, 46-55 років - 15,8 \%, 56-65 років - 8,4\%, 66 і більше років - 5,9 \% опитаних. У міській місцевості проживали 80,3 \%, а в сільській - 19,7 \% опитаних. За соціальним станом найбільшу частку серед опитаних склали службовці (37,1 \%) та студенти (24,2 \%); робітників серед опитаних було $15,4 \%$, пенсіонерів - 10,2 \%, приватних підприємців - 4,7\%, фрермерів - 3,1\%, безробітних - 3,1 \%, на інші соціальні статуси вказали 2,1 \% опитаних.

Соціологічним дослідженням менеджерів охоплено 135 фрахівців (керівників закладів охорони здоров'я і викладачів кафедр соціальної медицини та громадського здоров'я), з яких $60 \%$ становили чоловіки, 40 \% - жінки. У вибірці представлено менеджерів різних вікових груп, у тому числі до 35 років - 5,2 \%; 36-45 років - 26,7 \%, 46-55 років - 36,3 \%; 56-65 років - 21,5 \%, 66 і більше років - 10,4 \%. Ступінь кандидата наук або доктора фрілософії мали 10,4 \% опитаних, а доктора наук - 11,1\%. Близько третини опитаних мали стаж 5-9 років (32,6\%), менше 5 років - 17,8 \%, 10-14 років - 14,1 \%, 15-19 років 8,9 \%, 20-24 роки - 9,6 \%, понад 25 років - 17,0\%. При цьому майже половина (43,0 \%) мала стаж на теперішній посаді менше 5 років, ще 32,6 \% 5-9 років. Спеціальності, за якими опитані працювали на посаді менеджера охорони здоров'я, поділилися таким чином: організація і управління охороною здоров'я (спеціалізація 2 міс.) - 71,7 \% респондентів, менеджмент - 17,0 \%, організація і управління охороною здоров'я (спеціалізація 18 міс.) - 12,6 \%, державне управління (публічне адміністрування) - 11,9 \%, громадське здоров'я 8,9 \%, економіка - 3,0 \%, право - 0,7 \%. Частина респондентів (4,4 \%) вказала інші (лікарські) спеціальності.

Завданнями дослідження передбачено вивчити думку пацієнтів і менеджерів охорони здоров'я щодо якості та доступності лікувально-профрілактичної роботи в закладах охорони здоров'я; визначити проблеми здійснення професійної діяльності; виявити проблеми ресурсного забезпечення системи охорони здоров'я за умов ре- формування галузі з точки зору менеджерів охорони здоров'я.

Об'єктом дослідження є організація дерматовенерологічної медичної допомоги населенню. Предметом дослідження стали обсяги діяльності дерматовенерологічної служби, позиція пацієнтів щодо доступності та якості медичної допомоги дерматовенерологічного профілю, позиція менеджерів охорони здоров'я щодо ризиків трансформації дерматовенерологічної служби за умов реформування охорони здоров'я, потреби в ресурсному та організаційному забезпеченні.

Статистичну обробку та математичний аналіз матеріалів дослідження проведено зі застосуванням програми «EXCEL», з використанням сучасних методів статистичного аналізу.

Результати дослідження та їх обговорення. Стан здоров'я населення фрормує базу для визначення потреб широкого спектра послуг, насамперед медичних. Важливими аспектами цього є врахування суспільної думки зацікавлених категорій населення, у тому числі споживачів таких послуг пацієнтів, яким може виявитися кожен житель країни, а також менеджерів охорони здоров'я, метою діяльності яких $є$ не лише втілення в систему охорони здоров'я нових методів господарювання 3 використанням елементів ринкових відносин, але, насамперед, забезпечення дотримання пацієнт-орієнтованого підходу в діяльності підпорядкованих закладів охорони здоров'я.

Соціологічним опитуванням пацієнтів встановлено, що 40,8土2,2 на 100 опитаних зверталися до лікаря-дерматовенеролога за направленням сі-

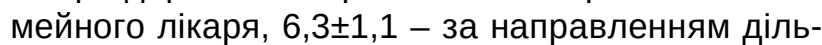
ничного терапевта, 10,2ะ1,3 - за направленням

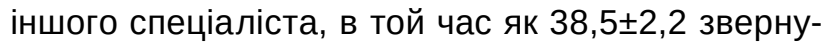
лися за дерматовенерологічною допомогою самостійно.

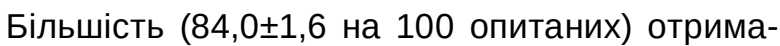
ла дерматовенерологічну допомогу в закладах комунальної форми власності (обласний, районний, міський диспансер, відділення районної чи міської лікарні, клініко-діагностичний центр), ще

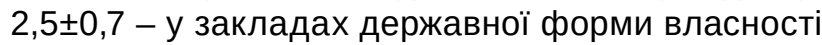
(Інститут дерматології та венерології Національної академії медичних наук України, профрільні кафедри закладів вищої медичної освіти). У приватних закладах охорони здоров'я медичну допомогу дерматовенерологічного профрілю отримали $8,2 \pm 1,2$ на 100 опитаних.

Доступність дерматовенерологічної допомоги респонденти оцінювали за чотирма ознаками: територіальна доступність («чи зручно розташований заклад, де надають таку допомогу?»), фрінансова доступність («чи існує фрінансова можливість отримати таку допомогу?»), транспортна доступність («чи наявні транспортні маршрути, якими 
зручно добиратися до лікаря-дерматовенеролога?») та психологічна доступність («чи комфортно звернутись та спілкуватись з лікарем-дерматовенерологом?»). Результати наведено у таблиці 1.

Таблиця 1. Оцінка пацієнтами доступності дерматовенерологічної допомоги (на 100 опитаних)

\begin{tabular}{|l|c|c|c|c|}
\hline \multirow{2}{*}{\multicolumn{1}{|c|}{ Оцінка респондентів }} & \multicolumn{4}{|c|}{ Види доступності допомоги } \\
\cline { 2 - 5 } & територіальна & срінансова & транспортна & психологічна \\
\hline Складно дати оцінку & $10,9 \pm 1,4$ & $31,4 \pm 2,1$ & $6,4 \pm 1,1$ & $21,3 \pm 1,8$ \\
\hline Низька доступність & $13,3 \pm 1,5$ & $28,5 \pm 2,0$ & $14,8 \pm 1,6$ & $3,9 \pm 0,9$ \\
\hline Невисока доступність & $34,6 \pm 2,1$ & $31,3 \pm 2,0$ & $43,9 \pm 2,2$ & $29,7 \pm 2,0$ \\
\hline Висока доступність & $41,0 \pm 2,2$ & $8,8 \pm 1,3$ & $34,8 \pm 2,1$ & $43,2 \pm 2,2$ \\
\hline Дуже висока доступність & $0,2 \pm 0,2$ & $0,0 \pm 0,0$ & $0,0 \pm 0,0$ & $2,0 \pm 0,6$ \\
\hline
\end{tabular}

Оцінюючи причини проблем із доступністю, більшість респондентів вказала на відсутність зручної комунікації 3 лікарем щодо оптималь-

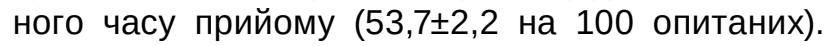
Водночас 41,8 2 2,2 відзначили нерівномірність навантаження на дерматовенеролога у різні дні тижня, 40,0 2,2 - велике навантаження на ліка-

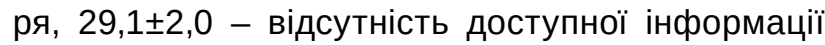

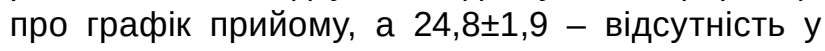
найближчому закладі охорони здоров'я лікарядерматовенеролога.

На думку понад половини опитаних, вони отримали достатньо якісну дерматовенерологічну ме-

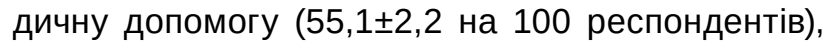

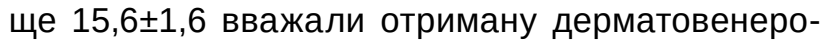
логічну допомогу якісною. Водночас 27,3 2 2,0 оцінили цю медичну допомогу як недостатньо якісну і 2,0土0,6 - як низької якості.

Погіршують якість надання дерматовенерологічної допомоги, на думку майже двох третин респондентів, насамперед недостатня оснащеність

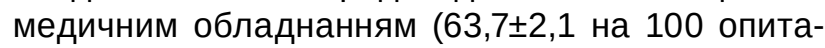
них) та недостатня оснащеність комп'ютерним обладнанням $(58,0 \pm 2,2)$. Як вагомі причини недостатньо якісної дерматовенерологічної допомоги відзначено також недостатнє забезпечення закладу лікарськими засобами, витратними матеріалами $(42,6 \pm 2,2)$, незручний час прийому $(36,5 \pm 2,1)$, недостатнє інформування фахівцями пацієнтів про причини захворювання, способи і методи профілактики, діагностики, лікування, безпечність процедур тощо $(33,4 \pm 2,1)$, незадовільні умови праці (опалення, освітлення, санітарні умови приміщення тощо) $(29,7 \pm 2,0)$, призначення дороговартісних ліків $(25,6 \pm 1,9)$, наявність черги на прийом до лікаря $(25,6 \pm 1,9)$, перевантаженість лікаря $(25,4 \pm 1,9)$, відсутність медичної сестри на прийомі $(21,5 \pm 1,8)$. Проблеми етикодеонтологічного характеру та питання компетентності лікаря більшість респондентів не зараховували до таких, що знижували якість наданої їм допомоги. Серед недоліків обслуговування відзначили такі, як: недостатня увага, зверхнє ставлення фрахівців до пацієнта $(15,4 \pm 1,6$ на 100 опитаних), неетична поведінка медичного персоналу $(2,5 \pm 0,7)$, вимагання незаконної винагороди $(0,4 \pm 0,3)$; незадовільні результати лікування $(6,1 \pm 1,1)$ та недостатня компетентність медичного персоналу $(4,7 \pm 0,9)$.

Ситуація, пов'язана з розвитком пандемії коронавірусної хвороби COVID-19 та протидією їй, на думку опитаних пацієнтів, по-різному вплинула на якість та доступність дерматовенерологічної допомоги (рис. 1 і 2): якщо якість, на думку $53,7 \pm 2,2$ зі 100 опитаних, не змінилася, то доступність дещо погіршилася $(47,1 \pm 2,2)$ або погіршилася $(15,2 \pm 1,6)$ (рис. 1, 2).

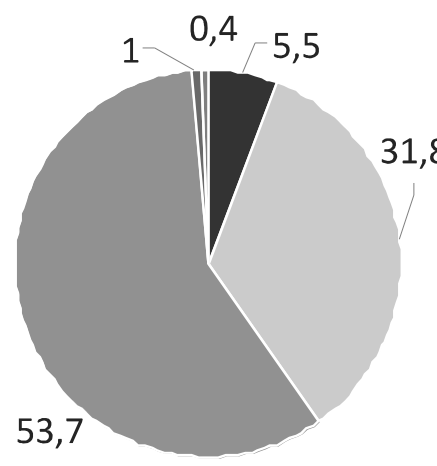

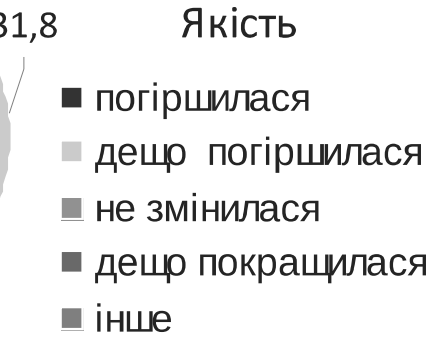

Рuc. 1. Оцінка пацієнтами впливу ситуації, пов'язаної з розвитком пандемії COVID-19, на якість дерматовенерологічної допомоги (на 100 опитаних).

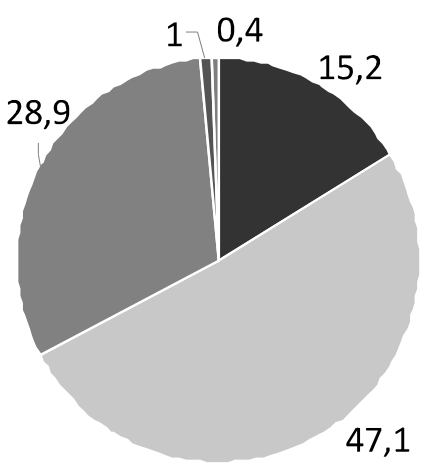

Доступність - погіршилася дещо погіршилася ве змінилася - дещо покращилася 口 інше

Рuc. 2. Оцінка пацієнтами впливу ситуації, пов'язаної з розвитком пандемії COVID-19, на доступність дерматовенерологічної допомоги (на 100 опитаних). 
Для підвищення доступності та якості медичних послуг дерматовенерологічного профрілю, на думку більшості респондентів, доцільне оснащення закладів сучасним медичним та комп'ютерним обладнанням (64,8土2,1 на 100 опитаних); запровадження попередньої дистанційної діагностики за допомогою телемедицини, мобільних додатків тощо $(57,6 \pm 2,2)$; поліпшення умов праці медичного персоналу $(47,7 \pm 2,2)$; поліпшення забезпечення закладу лікарськими засобами, витратними матеріалами $(46,5 \pm 2,2)$; більш зручний графрік прийому пацієнтів.

Респонденти пропонували передбачити більше часу на прийом кожного пацієнта (36,3土2,1 на 100 опитаних); достатнє інорормування пацієнтів про причини захворювання, способи і методи профрілактики, діагностики, лікування, безпечність процедур тощо $(35,7 \pm 2,1)$; підвищення уваги медичного персоналу до проблем пацієнта $(30,3 \pm 2,0)$; координацію прийому хворих із медичною сестрою $(26,6 \pm 2,0)$; збільшення кількості фрахівців дерматовенерологічного профрілю $(26,4 \pm 1,9)$; поліпшення комунікацій 3 пацієнтами, дотримання норм медичної етики $(19,1 \pm 1,7)$; підвищення рівня знань і компетентності персоналу $(19,1 \pm 1,7)$; призначення більш ефективних та безпечних методів лікування $(10,7 \pm 1,4)$.

Соціологічне опитування менеджерів охорони здоров'я показало, що, на думку більшості респондентів, негативно впливають на ефективність роботи фахівців та якість медичних послуг дерматовенерологічного профілю недостатнє

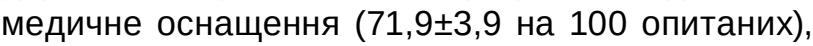
погана технологічна забезпеченість $(66,7 \pm 4,1)$, брак комп'ютерного обладнання $(57,8 \pm 4,3)$, мотиваційні та стимуляційні чинники: відсутність мотиваційних важелів до підвищення якості роботи $(52,6 \pm 4,3)$, неадекватна оплата праці $(48,9 \pm 4,3)$, обмежені перспективи побудови кар'єри $(48,9 \pm 4,3)$.

Серед інших можливих несприятливих чинників управлінці відзначали: незадовільне інорормаційне забезпечення $(40,7 \pm 4,2)$, незадовільну координацію діяльності з колегами, допоміжними підрозділами $(37,8 \pm 4,2)$, недостатню можливість безперервного професійного розвитку $(28,1 \pm 3,9)$, незадовільну організацію праці $(24,1 \pm 3,7)$, недоукомплектованість штатних посад персоналу $(20,7 \pm 3,5)$, проблеми 3 доступністю до мережі «Інтернет» $(17,8 \pm 3,3)$, несприятливий психологічний клімат у колективі $(10,4 \pm 2,6)$, незадовільні санітарні умови $(6,7 \pm 2,1)$.

Водночас менеджери вказали на ті чинники, які позитивно впливають на ефективність роботи та якість медичних послуг дерматовенерологічного профрілю. Серед них, насамперед, більшість респондентів назвала належну оснащеність медичним обладнанням (77,0 3,6 на 100 опита- них), впровадження новітніх медичних технологій $(74,1 \pm 3,8)$, належну оснащеність комп'ютерним обладнанням $(70,4 \pm 3,9)$, впровадження нових технологій організації праці $(65,9 \pm 4,1)$, адекватне інфрормаційне забезпечення, у тому числі доступність до мережі «Інтернет» на робочому місці $(65,9 \pm 4,1)$, систему матеріальних (премії, доплати тощо) та нематеріальних стимулів $(63,0 \pm 4,2)$, можливість безперервного професійного розвитку $(58,5 \pm 4,2)$, злагоджену роботу усіх фрахівців і підрозділів $(50,4 \pm 4,3)$.

Іншими сприятливими чинниками вказано: можливість побудови успішної кар'єри $(45,2 \pm 4,3)$, належні санітарні умови праці $(35,6 \pm 4,1)$, зручний графрік роботи $(34,1 \pm 4,1)$, регулярна заробітна платня $(32,6 \pm 4,0)$, висока укомплектованість посад фрізичними особами $(30,4 \pm 4,0)$, сприятливі психологічні стосунки в колективі $(30,4 \pm 4,0)$.

Оцінюючи вплив ситуації, пов'язаної з розвитком пандемії коронавірусної хвороби COVID-19, опитані менеджери охорони здоров'я відзначали суттєву її роль у зменшенні доступності дерматовенерологічної допомоги для пацієнтів та погіршенні якості обслуговування (рис. 3, 4). Зменшення доступності дерматовенерологічної допомоги підтвердили 63,0 на 100 опитаних, у тому числі деяке погіршення відзначили $(41,5 \pm 4,0)$ респон-

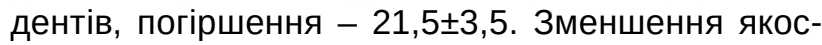
ті допомоги через пандемію підтвердили 26,7 на 100 опитаних, на думку 67,4ะ4,0 зі 100 респондентів, якість послуг не змінилася. Покращення якості та доступності дерматовенерологічної допомоги респонденти не відзначали.

Більшість опитаних менеджерів охорони здоров'я зазначила, що узагальнена оцінка кваліфрікації вітчизняних дерматовенерологів $€$ середньою $(74,8 \pm 3,7$ на 100 опитаних), на думку

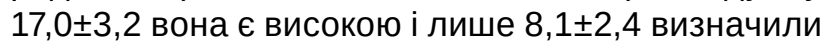
кваліфрікацію дерматовенерологів як недостатню. Водночас більшість респондентів (89,6 2 2,6 на 100 опитаних) відзначила, що наявність у лікаря більш високої кваліфрікаційної категорії насправді

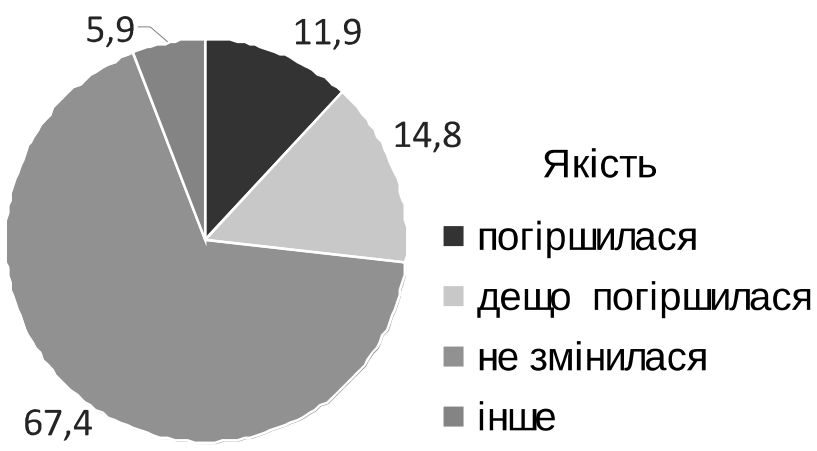

Рис. 3. Оцінка менеджерами охорони здоров'я впливу ситуації, пов'язаної з розвитком пандемії COVID-19, на якість дерматовенерологічної допомоги (на 100 опитаних). 


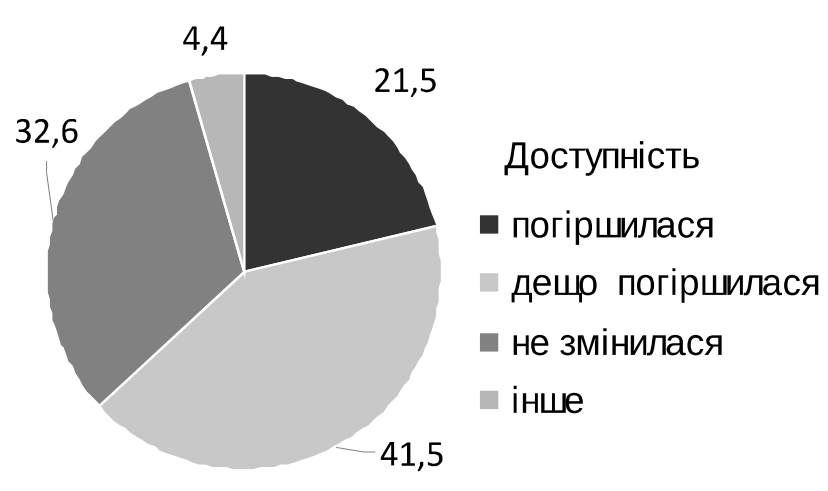

Рuc. 4. Оцінка менеджерами охорони здоров'я впливу ситуації, пов'язаної з розвитком пандемії COVID-19, на доступність дерматовенерологічної допомоги (на 100 опитаних).

не завжди відображає його більш високу кваліфрікацію.

На думку опитаних менеджерів охорони здоров'я, 3 метою підтримання та підвищення належної кваліфікації дерматовенерологів найважливішими $є$ такі форми безперервного професійного розвитку (БПР): шляхом участі у вітчизняних науково-практичних фрорумах $(60,7 \pm 4,2$ на 100 опитаних), у закордонних науково-практичних форумах $(57,8 \pm 4,3)$, на основі виїзних форм навчання, у тому числі тренінгів на робочих місцях $(51,1 \pm 4,3)$, шляхом участі у вітчизняних науково-практичних фрорумах за участю зарубіжних спеціалістів $(48,1 \pm 4,3)$, на основі дистанційної форми $(47,1 \pm 4,3)$. Інші фрорми БПР виявилися важливими на думку менше третини респондентів: регулярне читання фрахових періодичних видань, у тому числі електронних $(26,7 \pm 3,8)$, підвищення кваліфікації на курсах за бюджетні кошти (за путівками) $(24,4 \pm 3,7)$, на курсах на комерційній основі (за власні, спонсорські кошти тощо) $(23,7 \pm 3,7)$, на тематичних циклах $(20,7 \pm 3,5)$, обмін досвідом 3 колегами, у тому числі в соціальних мережах $(20,7 \pm 3,5)$, вивчення нормативно-директивних джерел $(17,0 \pm 3,2)$, знаходження інформації в мережі «Інтернет» у разі потреби $(13,3 \pm 2,9)$.

Оцінюючи ресурсне, насамперед матеріальнотехнічне забезпечення закладів, у яких надають дерматовенерологічну допомогу, більшість менеджерів оцінила його стан як такий, що імовірніше відповідає сучасним вимогам $(60,6 \pm 3,9$ на

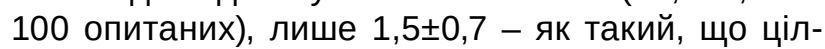
ком відповідає сучасним вимогам. Вважали, що матеріально-технічне забезпечення закладів дерматовенерологічного профрілю імовірніше не відповідає сучасним вимогам 25,8土3,2 на 100 рес-

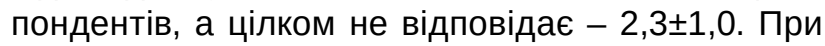
цьому респонденти вказували на застаріле діагностичне обладнання, дефріцит витратних матеріалів, недостатнє забезпечення комп'ютерною технікою, проблеми 3 підключенням до мережі «lнтернет» та інші проблемні питання, що можуть перешкоджати впровадженню сучасних електронних технологій.

У ході дослідження думки організаторів охорони здоров'я встановлено потребу в удосконаленні лікувально-діагностичних технологій, методів роботи у закладах і підрозділах дерматовенерологічного профрілю. Більшість респондентів вказала на часткову потребу в оптимізації технологічної оснащеності та удосконаленні методів роботи

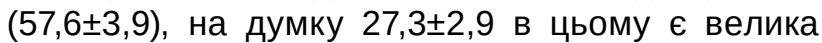
потреба і лише 7,6士1,6 на 100 опитаних зазначили, що такої потреби немає. Конкретизуючи цю потребу, менеджери зазначали доцільність запровадження дистанційних скринінгово-моніторингових технологій - телемедицини, мобільної медицини, а також поширення практики використання цифрової дерматоскопії, ультразвукової діагностики шкіри, патогістології шкіри, лазерних та радіохвильових апаратних технологій лікування.

Більшість респондентів визнала, що оплата праці лікарів-дерматовенерологів, як правило,

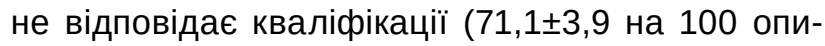

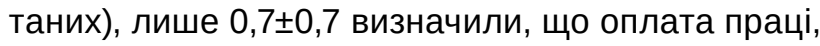
як правило, відповідає кваліфікації, а 27,4士3,8 не змогли визначитися 3 точною відповіддю.

Більшість менеджерів охорони здоров'я визнала себе тією чи іншою мірою поінформованою 3 питань реформ у вітчизняній охороні здоров'я: поінфрормовані (50,4ะ4,3 на 100 опитаних), добре поінформовані $(25,2 \pm 3,7)$, а дещо поінформовані $(23,0 \pm 3,6)$. Зовсім не поінформованими 3 цих питань не визнав себе жоден респондент. Складно оцінити свою поінформованість виявилося для $1,5 \pm 1,0$ на 100 опитаних. Рівень поінформованості з питань рефрормування організаційних засад дерматовенерологічної служби у більшості менеджерів охорони здоров'я виявився достатнім різною мірою: частково достатній у 38,5 $\pm 4,2$

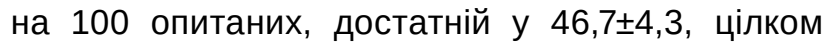
достатній у $3,0 \pm 1,5$, а недостатній - лише у $11,9 \pm 2,8$ на 100 опитаних.

Характеризуючи перспективи розвитку відділення чи закладу охорони здоров'я, в якому працюють респонденти, в рефрормованій системі охорони здоров'я, більшість менеджерів визначила свою поінформованість як часткову $(72,6 \pm 3,8)$,

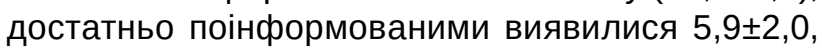
а недостатність поінформованості визнали 21,5ะ3,5 на 100 опитаних, що може свідчити про недостатній рівень зовнішніх та внутрішніх комунікацій у відповідних закладах охорони здоров'я та відсутність у них дієвих комунікаційних стратегій.

Оцінюючи можливі зміни у дерматовенерологічній службі, які, на думку опитаних менеджерів охорони здоров'я, відбудуться у разі завершення рефрормування системи охорони здоров'я, близько половини респондентів спрогнозували розши- 
рення перспектив профресійного розвитку співро-

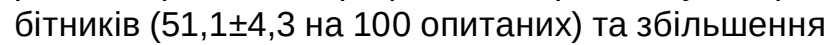
можливостей для гідного заробітку працівників $(48,1 \pm 4,3)$. Менша кількість респондентів передбачала зменшення кількості лікарів дерматовенерологічного профрілю $(37,0 \pm 4,2)$, скорочення фрінансування закладу $(36,3 \pm 4,1)$, збільшення обсягів дерматовенерологічних послуг $(23,0 \pm 3,6)$, ліквідацію закладу $(11,1 \pm 2,7)$, скорочення обсягів дерматовенерологічних послуг $(10,4 \pm 2,6)$, відсут-

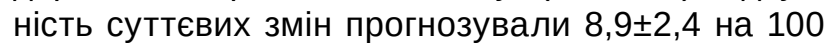
опитаних.

Результати соціологічного опитування пацієнтів - споживачів дерматовенерологічних послуг та менеджерів охорони здоров'я дали змогу виявити наявні проблеми в діяльності дерматовенерологічної служби на сучасному етапі розвитку охорони здоров'я. Вони засвідчили ставлення пацієнтів до стану свого здоров'я в контексті профрілактики, сприйнятті та розумінні ризику розвитку дерматовенерологічної патології, її вчасного виявлення та лікування, а також ставлення менеджерів до розвитку спеціалізованих медичних служб, до яких належить дерматовенерологічна служба. Різноаспектна оцінка стану надання дерматовенерологічної допомоги, її доступності та якості, виявлення наявних проблем організації профрілактичного та лікувальнодіагностичного процесів, впливу на них реформи охорони здоров'я та пандемії COVID-19 створили підґрунтя для визначення напрямів та заходів 3 удосконалення організації медичної допомоги.

Оцінка умов функціонування служби споживачами дерматовенерологічних послуг виявляє наявні виклики та підходи до відповіді на них, які необхідно реалізувати в роботі дерматовенерологічної служби. У цьому контексті потребують уваги невисока доступність дерматовенерологічної допомоги, аналіз причин зниження її якості, серед яких недостатнє оснащення медичним та комп'ютерним обладнанням, низька мотивація, недосконалі діагностичні та лікувальні технології, організаційні та управлінські проблеми, на що вказала більшість опитаних.

Пошук еорективних шляхів протистояння сучасним викликам та загрозам потребує врахування новітніх реалій, пов'язаних із виникненням і розвитком пандемії COVID-19, яка, на думку пацієнтів і менеджерів охорони здоров'я, зменшила доступність медичних послуг, знизила медичну активність пацієнтів дерматовенерологічного профрілю та ускладнила умови надання необхідної допомоги. Визначення бар'єрів, які перешкоджають якісному медичному обслуговуванню дерматовенерологічних пацієнтів, виявляє оптимальні напрями вдосконалення надання послуг та встановлює їх пріоритетність, окреслює потребу в міжсекторальному підході до вирішення проблем, залученні телемедичних, мобільних технологій, розбудови електронної охорони здоров'я, залучення до розвитку служби громадського здоров'я і її взаємодії з медичною мережею.

\section{Висновки}

Значні рівні дерматовенерологічної захворюваності населення України та їх соціальна значущість, потенційні негативні наслідки для здоров'я зумовлюють потребу в удосконаленні дерматовенерологічної служби.

Вивчення думки пацієнтів та менеджерів охорони здоров'я стосовно сучасного стану дерматовенерологічної служби, кадрового потенціалу, доступності та якості її послуг дозволило виявити низку організаційно-управлінських проблем, які стосуються нормативно-правового регулювання діяльності, причетних до профрілактики, діагностики та лікування, боротьби 3 дерматовенерологічною патологією служб, браку міждисциплінарного, міжсекторального співробітництва, недостатності ресурсного забезпечення, технологічного оснащення тощо.

Результати соціологічного опитування сприяли визначенню пріоритетів діяльності з подальшої розбудови системи дерматовенерологічної допомоги населенню за умов реформування охорони здоров'я з урахуванням сучасних викликів та загроз, у тому числі пандемії COVID-19; виявили необхідність в обґрунтуванні, створенні та запровадженні оптимізованої сучасної функціонально-організаційної моделі дерматовенерологічної служби.

Перспективи подальших досліджень стосуються розробки, імплементації, моніторингу подальшої ефективності та вивчення потреб у корекції окремих елементів комплексної функціонально-організаційної моделі дерматовенерологічної служби з урахуванням викликів і можливостей, що виявлятимуться в процесі її реалізації.

\section{Список літератури}

1. Кравченко В. Г. Аналітичний огляд рівня захворюваності на інфекції, що передаються статевим шляхом, у період 1945-2017 рр. та можливі перспективні заходи щодо зниження їхньої поширеності в Україні / В. Г. Кравченко, В. І. Степаненко // Український журнал дерматології, венерології, косметології. - 2018. - № 3 (70). - С. 15-21. 2. Національна стратегія реформування системи охорони здоров'я в Україні на період 2015-2020 роки [Електронний ресурс]. - Режим доступу : https://moz.gov.ua/strategija.

3. Особливості розповсюдження інфекцій, що передаються статевим шляхом, з урахуванням впливу ВІЛ-інфекції в Україні [Електронний ресурс] / Г. М. Бондаренко, Г. І. Мавров, Т. В. Осінська та ін. // Дерматологія та венерологія. 2017. - № 1. - С. 8-14. - Режим доступу : http://nbuv.gov.ua/UJRN/dtv_2017_1_3. 
4. Пашков В. М. Правове забезпечення реформування сфери охорони здоров'я [Електронний ресурс] / В. М. Пашков // Український медичний часопис. Актуальні питання медичної практики. - 2017. - № 2. - С. 1-6. - Режим доступу : https://www.umj.com.ua/article/107586/pravove-zabezpechennya-reformuvannya-sferi-ohoroni-zdorov-ya.

5. Про Цілі сталого розвитку України на період до 2030 року : Указ Президента України від 30 вересня 2019 року № 722/2019 [Електронний ресурс]. - Режим доступу : https://www.president.gov.ua/documents/7222019-29825 (дата звернення: 03.03.2020).

6. Щорічна доповідь про стан здоров'я населення, санітарно-епідемічну ситуацію та результати діяльності системи охорони здоров'я України. 2017 рік / Український інститут стратегічних досліджень МОЗ України ; редкол. : П. С. Мельник [та ін.]. - К. : Медінформ, 2018. - 458 с.

7. European Action Plan for Strengthening Public Health Capacities and Services. Copenhagen : WHO EURO, 2015. - 42 p. 8. Gruzieva T. Prerequisites for choosing an effective model of providing dermatovenerological care in Ukraine. International scientific and practical conference "New trends and unresolved issues of preventive and clinical medicine" September 25-26, 2020 / T. Gruzieva, V. Korolenko. - Lublin, Republic of Poland. - 2020. - P. 187-190. DOI: https://doi.org/10.30525/9789934-588-81-5-2.50

9. Maintaining essential health services: operational guidance for the COVID-19 context Interim guidance. Copenhagen : WHO EURO, 2020. - $61 \mathrm{p}$.

10. Omran A. R. The epidemiological transition: A theory of the epidemiology of population change. The Milbank Quarterly. 2005. - Vol. 83 (4). - P. 731-757.

11. Strengthening the health system response to COVID-19. Preventing and managing the COVID-19 pandemic across long-term care services in the WHO European Region (21 May 2020). Copenhagen: WHO EURO, 2020. - 32 p.

12. The toolkit for a sustainable health workforce in the WHO European Region. Copenhagen : WHO EURO, 2018. - 82 p. 13. World Health Organization. Tracking universal health coverage: first global monitoring report. WHO/World Bank Group report [Internet]. Geneva: WHO; 2015. URL : http://apps.who.int/iris/bitstream/10665/174536/1/9789241564977_eng. pdf?ua=1.

\section{References}

1. Kravchenko, V.H., \& Stepanenko, V.I. (2018). Analitychnyi ohliad rivnia zakhvoriuvanosti na infektsii, shcho peredaiutsia statevym shlyikhom, u period 1945-2017 rr. ta mozhlyvi perspektyvni zakhody shchodo znyzhennia yikhnoi poshyrenosti v Ukraini [Analytical review of the incidence of sexually transmitted infections in the period 1945-2017 and possible promising measures to reduce their prevalence in Ukraine]. Ukrainskyi zhurnal dermatolohii, venerolohii, kosmetolohii - Ukrainian Journal of Dermatology, Venereology, Cosmet, 3 (70), 15-21 [in Ukrainian].

2. Natsionalna stratehiia reformuvannia systemy okhorony zdorovia v Ukraini na period 2015-2020 roky [National strategy for reforming the health care system in Ukraine for the period 2015-2020]. Retrieved from: https://moz.gov.ua/strategija [in Ukrainian].

3. Bondarenko, G.M., Mavrov, G.I., Osinskaya, T.V., Shcherbakova, Yu.V., Nikitenko, I.M., Unuchko, S.V., Chirva, V.B., Teslenko, S.V., \& Barsukova, L.I. (2017). Osoblyvosti rozpovsiudzhennia infektsii, shcho peredaiutsia statevym shliakhom, z urakhuvanniam vplyvu VIL-infektsii v Ukraini [Features of the spread of sexually transmitted infections, taking into account the impact of HIV infection in Ukraine]. Dermatolohiia ta venerolohiia - Dermatology and Venereology, 1, 8-14 [in Ukrainian]. 4. Pashkov, V.M. (2017). Pravove zabezpechennia reformuvannia sfery okhorony zdorovia [Legal support for health care reform]. Ukrainskyi medychnyi chasopys. Aktualni pytannia medychnoi praktyky - Ukrainian Medical Journal. Current Issues of Medical Practice, 2, 1-6 [in Ukrainian].

5. (2020). Pro Tsili staloho rozvytku Ukrainy na period do 2030 roku. Ukaz Prezydenta Ukrainy vid 30 veresnia 2019 roku №722/2019 [On the Goals of sustainable development of Ukraine for the period up to 2030. Decree of the President of Ukraine of September 30, 2019 No. 722]. Prezydent Ukrainy. Retrieved from: https://uww.president.gov.ua/documents/7222019-29825 [in Ukrainian].

6. (2018). Shchorichna dopovid pro stan zdorovia naselennia, sanitarno-epidemichnu sytuatsiiu ta rezultaty diialnosti systemy okhorony zdorovia Ukrainy. 2017 rik [Annual report on the state of health of the population, the sanitary-epidemic situation and the results of the health care system of Ukraine. 2017]. Ukr. in-t strateh. doslidzh. MOZ Ukrayiny. Melnyk, P.S. (Ed.). Kyiv: Medinform [in Ukrainian].

7. (2015). European Action Plan for Strengthening Public Health Capacities and Services. Copenhagen: WHO EURO.

8. Gruzieva, T., \&Korolenko, V. (2020). Prerequisites for choosing an effective model of providing dermatovenerological care in Ukraine. International scientific and practical conference "New trends and unresolved issues of preventive and clinical medicine". Lublin, Republic of Poland, 187-190.

9. (2020). Maintaining essential health services: operational guidance for the COVID-19 context Interim guidance. Copenhagen : WHO EURO.

10. Omran A. R. (2005). The epidemiological transition: A theory of the epidemiology of population change. The Milbank Quarterly, 83 (4), 731-757.

11. (2020). Strengthening the health system response to COVID-19. Preventing and managing the COVID-19 pandemic across long-term care services in the WHO European Region (21 May 2020). Copenhagen: WHO EURO.

12. (2018). The toolkit for a sustainable health workforce in the WHO European Region. Copenhagen: WHO EURO.

13. (2015). World Health Organization. Tracking universal health coverage: first global monitoring report. WHO/World Bank Group report [Internet]. Geneva: WHO. Retrieved from: http://apps.who.int/iris/bitstream/10665/174536/1/9789241564977_ eng.pdf?ua=1. 


\section{ANALYSIS OF PROSPECTS OF DEVELOPMENT OF DERMATOVENEROLOGICAL SERVICE TAKING} INTO ACCOUNT THE OPINION OF PATIENTS AND HEALTHCARE MANAGERS

V. V. Korolenko, T. S. Gruzieva, H. V. Inshakova

O. Bohomolets National Medical University, Kyiv, Ukraine

Purpose: to assess the current state and problems of dermatovenereological care from the standpoint of patients and healthcare managers.

Materials and Methods. Bibliographic, medical-statistical, sociological methods were used. The scientific basis were the data of the scientific literature, data of own sociological researches of opinion of patients and healthcare managers concerning quality and availability of dermatovenereological care.

Results. Problems of availability and quality of dermatological care were identified by sociological research. More than a third of the surveyed patients rated territorial (34.6 \pm 2.1$)$ per 100 and financial (31.3 \pm 2.0$)$ dermatovenereological care as insufficient availability, as low - (13.3 \pm 1.5$)$ and $(28.5 \pm 2.0)$ respectively. The quality of care was considered insufficient, $(27.3 \pm 2.0)$ per 100 respondents. The causes of problems and ways to improve the availability and quality of dermatological care were determined, including improving the organization of services, the introduction of e-Health, improving resources, communication. Healthcare managers pointed to the reasons for insufficient efficiency of dermatovenereological care, including insufficient medical equipment $(71.9 \pm 3.9)$ and information support $(40.7 \pm 4.2)$, lack of computer equipment (57.8 \pm 4.3$)$, unsatisfactory coordination of activity with colleagues, auxiliary divisions, lack of interbranch interaction, lack of motivational levers, etc. There is the need for the introduction of remote technologies - telemedicine, mobile medicine, as well as the spread of the use of digital dermatoscopy, ultrasound skin diagnostics, skin pathohistology, laser and radio wave hardware treatment technologies. The opinion of patients and healthcare managers about the negative impact of the COVID-19 pandemic on the availability and quality of medical services has been confirmed.

Conclusions. The study of the opinion of patients and health managers on the current state of the dermatovenereology service, human resources, availability and quality of its services, revealed a number of organizational and managerial problems and identified priorities for further development of dermatovenereology in health care reform, to substantiate the conceptual principles of building its improved functional and organizational model.

KEY WORDS: organization of medical care; dermatovenereological care; availability; quality; patients; managers; sociological research; telemedicine technologies; resource provision; COVID-19; reforming.

Рукопис надійшов до редакції 01.09.2020 р.

\section{Відомості про авторів:}

Короленко Володимир Васильович - кандидат медичних наук, магістр державного управління у сфері охорони здоров'я, докторант кафредри соціальної медицини та громадського здоров'я Національного медичного університету імені О. О. Богомольця; тел.: +38(044) 422-55-73.

Грузєва Тетяна Степанівна - доктор медичних наук, професор, завідувач кафедри соціальної медицини та громадського здоров'я Національного медичного університету імені О. О. Богомольця; тел.: +38(044) 236-01-22. Іншакова Ганна Вадимівна - кандидат педагогічних наук, доцент, доцент кафедри соціальної медицини та громадського здоров'я Національного медичного університету імені О. О. Богомольця; тел.: +38(044) 236-01-22. 